\section{Growth Response of Snap Bean and Tomato as Affected by Salinity and Irrigation Method}

\author{
J.M.S. Scholberg ${ }^{1}$ and S.J. Locascio ${ }^{2}$ \\ Horticultural Sciences Department, Institute of Food and Agricultural Sciences, \\ University of Florida, Gainesville, FL 32611-0690
}

Additional index words. Phaseolus vulgaris, Lycopersicon esculentum, drip irrigation, subirrigation, microirrigation, water quality, seed germination, nutrient content, yield

\begin{abstract}
Although the effects of salinity on yield of tomato(Lycopersicon esculentum Mill.) grown under arid and semiarid conditions are well known, little information is available on the effects of salinity on crops grown in more humid conditions. In Florida, availability of high-quality water for irrigation may be reduced because of increased domestic consumption and sea water intrusion. Two greenhouse studies were conducted to determine the influence of irrigation system and water quantity and quality on the growth of tomato and snap bean (Phaseolus vulgaris $\mathrm{L}$.). Bean plant heights and weights were greater with drip irrigation than with subirrigation. Bean seed germination percentage, plant height, and shoot weight decreased linearly with an increase in electrical conductivity of irrigation water $\left(E C_{i}\right)$ from 1 to $4 \mathrm{dS} \cdot \mathrm{m}^{-1}$. Tomato leaf water potential and plant height decreased linearly with increasing salinity. Tomato stem and leaf weights were greatest at the intermediate salinity $\left(2 \mathrm{dS} \cdot \mathrm{m}^{-1}\right)$ during initial growth, and stem weights decreased linearly with increased salinity during flowering. With drip irrigation, concentration of $N$ for both crops decreased and concentration of $P$ increased with an increase in water application from 0.75 to 1.5 times the estimated evapotranspiration rate $\left(\mathrm{ET}_{\mathrm{a}}\right)$. Tomato and bean tissue Na concentrations increased linearly with increased salinity. Total fruit yield and average fruit weight decreased linearly in tomato, and marketable fruit yield decreased quadratically with increased salinity.
\end{abstract}

In Florida, most vegetables are grown during periods of low rainfall and irrigation is required for high yields and good quality. However, increased water consumption in Florida is likely to increase the salinity in many wells, and therefore could reduce the availability of high-quality irrigation water for vegetable production.

With the use of nonsaline water, yields of most crops increase linearly with actual evapotranspiration $\left(\mathrm{ET}_{\mathrm{a}}\right)$ until a maximum level of evapotranspiration $\left(\mathrm{ET}_{\mathrm{p}}\right)$ is reached (Vinten et al., 1986). Maximum yields for drip-irrigated tomato have been obtained at 0.75 to 1.0 times pan evaporation when nonsaline water was used for irrigation (Locascio and Smajstrla, 1996). With the use of saline water, accumulation of salts may cause deviation from such linearity, and additional irrigation (the leaching requirement) may be needed to minimize yield reductions (Vinten et al., 1986).

Received for publication 15 June 1998. Accepted for publication 17 Sept. 1998. Florida Agricultural Experiment Station Journal Series No. R-05071. We gratefully acknowledge M. Alligood for his technical assistance and B.L. McNeal for his suggestions and review of this work. Trade names are for information only and do not imply endorsement by the authors or the Univ. of Florida. The cost of publishing this paper was defrayed in part by the payment of page charges. Under postal regulations, this paper therefore must be hereby marked advertisement solely to indicate this fact.

${ }^{1}$ Graduate Student.

${ }^{2}$ Professor; SJL@ GNV.IFAS.UFL.EDU
Drip irrigation, combined with polyethylene mulch, facilitates the efficient use of water and fertilizer so that similar or higher yields can be obtained with less water (Locascio and Smajstrla, 1996). With subirrigation, water use may be up to 10 times that with drip irrigation (Pitts et al., 1988) and, with the use of low-quality water, salt accumulation in the upper portions of the root zone may be appreciable (Hoffman, 1986). With drip irrigation, the maintenance of a moist, highly leached
Table 1. Preliminary soil-test values for the experimental soils.

Table 2. Fertilization schedule used for Expts. 1 and 2. $\mathrm{KCl}(0 \mathrm{~N}-0 \mathrm{P}-50 \mathrm{~K})$. root zone should allow the use of lower quality water (Hoffman, 1986), and when combined with fertigation, may also reduce early-season salinity stress related to fertilizer salts.

Little information is available on the use of marginal quality water (electrical conductivity between 1 and $3 \mathrm{dS}^{-1}$ ) for the irrigation of vegetables under humid weather conditions. An evaluation of production areas in Florida affected by salt water intrusion showed that $90 \%$ of the wells tested fell within the 1 to 4 $\mathrm{dS}^{-1}$ range (Steinkampf, 1982). Tomato is considered to be moderately salt tolerant whereas bean is fairly sensitive to salinity stress (Goertz and Coons, 1991). For tomato, reported $\mathrm{EC}_{\mathrm{i}}$ values at which initial and $50 \%$ yield reductions occur were 1.7 and $5.0 \mathrm{dS} \cdot \mathrm{m}^{-1}$, compared with 0.7 and $2.4 \mathrm{dS} \cdot \mathrm{m}^{-1}$ for bean (Ayers and Westcott, 1976). Plant salt tolerance may vary with growth stage and may also interact with other environmental factors (Meiri and Plaut, 1985; Pasternak, 1987). Moderate salinity may be beneficial to crops by limiting excessive vegetative growth and improving fruit quality (Mitchell et al., 1991).

In this study, it was hypothesized that with drip irrigation, salts are continually leached below the root zone, and that this allows the use of lower quality irrigation water. This effect should be most pronounced with irrigation at a rate greater than $\mathrm{ET}_{\mathrm{a}}$. In contrast, with the use of subirrigation, salt should accumulate near the soil surface in concentrations higher than in the irrigation water, and this may result in appreciable growth reduction as the season progresses. The objectives of this research were to determine the effects of irrigation system and salinity of the irrigation water $\left(\mathrm{EC}_{\mathrm{i}}\right)$ on growth of two crops differing in salt tolerance, and to evaluate the effects of irrigation quantity on drip-irrigated plants.

\section{Materials and Methods}

Two irrigation experiments were conducted in a greenhouse at the Univ. of Florida, Gainesville. In the first experiment, three 1-

\begin{tabular}{|c|c|c|c|c|c|c|c|c|c|}
\hline \multirow[b]{3}{*}{ Expt. } & \multirow[b]{3}{*}{$\mathrm{pH}$} & \multicolumn{8}{|c|}{ Extractable concn $\left(\mathrm{mg} \cdot \mathrm{L}^{-1}\right)$} \\
\hline & & \multicolumn{4}{|c|}{ Mehlich-1 extractable } & \multicolumn{4}{|c|}{$\mathrm{H}_{2} \mathrm{O}(2: 1 \mathrm{w} / \mathrm{w})$ extr. } \\
\hline & & $\mathrm{P}$ & $\mathrm{K}$ & $\mathrm{Mg}$ & $\overline{\mathrm{Ca}}$ & $\overline{\mathrm{Na}}$ & $\mathrm{Cl}$ & $\mathrm{NH}_{4}-\mathrm{N}$ & $\mathrm{NO}_{3}-\mathrm{N}$ \\
\hline 1 & 7.3 & 154 & 34 & 45 & 798 & 4 & 21 & 6.0 & 3.6 \\
\hline 2 & 6.6 & 164 & 20 & 91 & 1040 & 25 & 38 & 0.5 & 7.0 \\
\hline
\end{tabular}

\begin{tabular}{lcc}
\hline \hline Application time & No. applications & $\mathrm{N}-\mathrm{P}-\mathrm{K}^{\mathrm{z}}(\mathrm{g} / \mathrm{pot})$ \\
\hline & Expt. 1 & \\
Preplant & 1 & $1.0-2.0-1.0$ \\
Weeks 1-6 & 6 & $1.2-0.0-1.2$ \\
Weeks 7-14 & 8 & $2.4-0.0-2.4$ \\
Total & & $4.6-2.0-4.6$ \\
& Expt. 2 & \\
Preplant & 1 & $1.0-1.0-1.0$ \\
Weeks 1-6 & 6 & $1.2-0.0-1.2$ \\
Weeks 7-14 & 8 & $3.2-0.0-3.2$ \\
Total & & $5.4-1.0-5.4$ \\
\hline
\end{tabular}

${ }^{2} \mathrm{~N}$ source was $\mathrm{NH}_{4} \mathrm{NO}_{3}(34 \mathrm{~N}-0 \mathrm{P}-0 \mathrm{~K})$, P source was triple superphosphate $(0 \mathrm{~N}-2 \mathrm{P}-0 \mathrm{~K})$, and $\mathrm{K}$ source was 


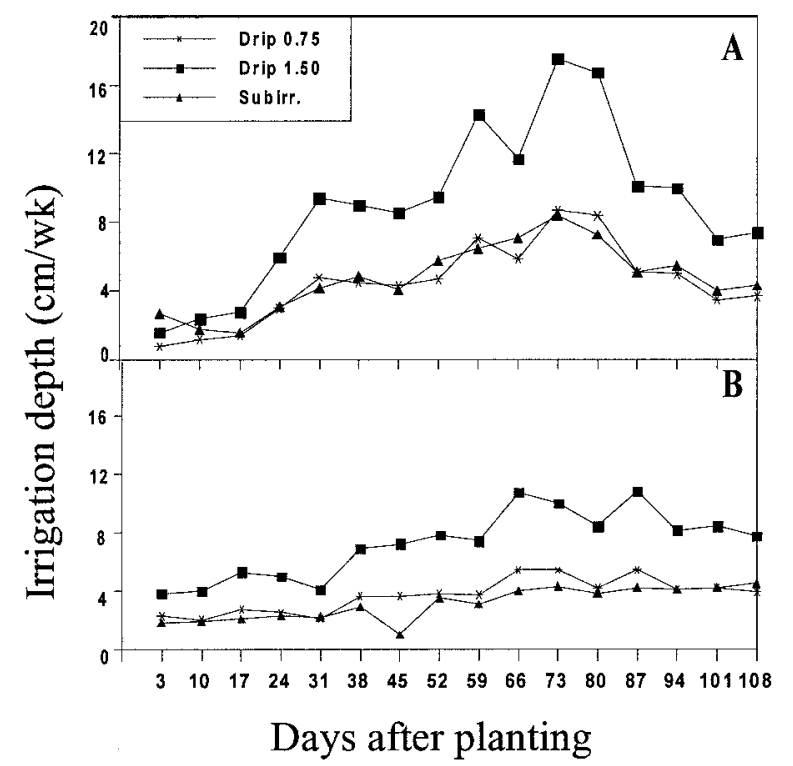

Fig. 1. Total weekly irrigation depths applied during Expt. 1 (A) and Expt. 2 (B).

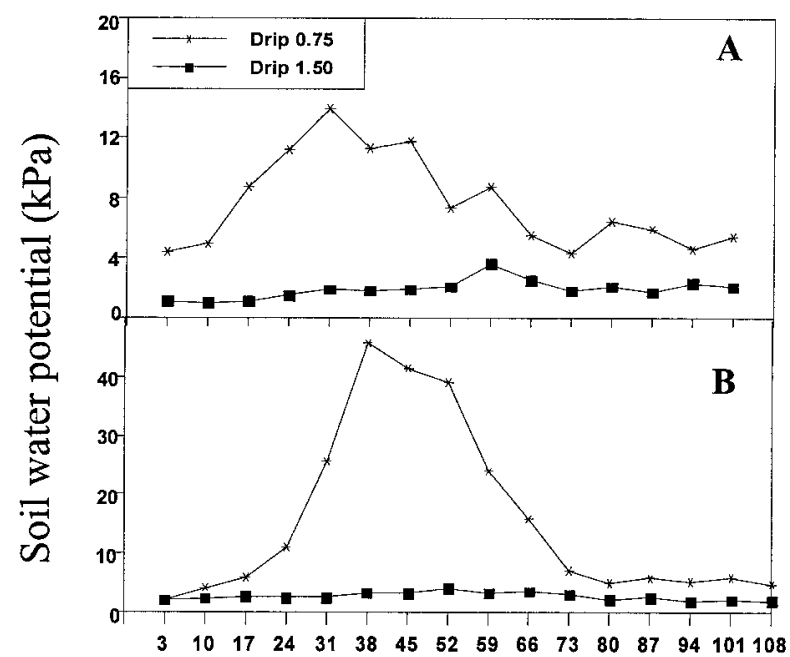

Days after planting

Fig. 2. Average preirrigation soil water potential at $15-\mathrm{cm}$ depth for dripirrigated intermediate salinity treatments $\left(\mathrm{EC}_{\mathrm{i}}=2\right)$ for Expt. $1(\mathbf{A})$ and Expt. 2 (B). month-old 'Sunny' tomato seedlings and 'Strike' bean seeds were planted on 10 Jan. 1991 in 32-cm-tall 15-L plastic pots. In the second experiment, both crops were planted in 34-cm-tall 19-L plastic pots on 5 Sept. 1991. Pots were filled with Pelham loamy sand (loamy, siliceous, thermic, Arenic Paleaquults). Preplant soil $\mathrm{pH}$ values $(2: 1, \mathrm{w} / \mathrm{w})$ and soil bulk densities ranged from 6.6-7.3 and 1.41$1.44 \mathrm{~g} \cdot \mathrm{cm}^{-3}$, respectively, and the EC value of a soil extract $(2: 1, \mathrm{w} / \mathrm{w})$ was $0.2 \mathrm{dS} \cdot \mathrm{m}^{-1}$. Preliminary soil test values for both soils are presented in Table 1, and the available soil moisture contents were 0.06 and $0.12\left(\mathrm{~cm}^{3} \cdot \mathrm{cm}^{3}\right.$ soil), respectively. Fertilizer (N, P, and K) was mixed with each soil before planting and/or added weekly with the irrigation water ( $\mathrm{N}$ and $\mathrm{K})$. An outline of the fertilization schedule is presented in Table 2.

Pots were spaced $0.5 \times 0.5 \mathrm{~m}$, and treatments were arranged in a randomized complete-block design with four replicates. Treatments were factorial combinations of: 1) two irrigation methods, drip irrigation and subirrigation; and 2) three salinity concentrations of irrigation water $\left(\mathrm{EC}_{\mathrm{i}}=1,2\right.$, and 4 $\left.\mathrm{dS} \cdot \mathrm{m}^{-1}\right)$. Drip irrigation was applied at 0.75 times $\left(\right.$ Drip $\left._{0.75}\right)$ and $1.50\left(\right.$ Drip $\left._{1.50}\right)$ times ET $_{a}$. Evapotranspiration $\left(\mathrm{ET}_{\mathrm{a}}\right.$ ) was measured only for each of the three Drip ${ }_{1.50}$-salinity treatments by collecting the water loss from two additional reference pots placed adjacent to each treatment. For subirrigation (SI), water was applied at 1.00 times $\mathrm{ET}_{\mathrm{a}}$. Average daylength ranged from 10.5 to $13 \mathrm{~h}$, and average light intensities were 550 and $600 \mu \mathrm{mol} \cdot \mathrm{m}^{-2} \cdot \mathrm{s}^{-1}$ for Expts. 1 and 2, respectively. The greenhouse was cooled by a pad-fan evaporative cooling system. Average minimum temperatures were 20.9 and $18.7^{\circ} \mathrm{C}$ and average maximum temperatures were 32.9 and $25.3^{\circ} \mathrm{C}$, for Expts. 1 and 2, respectively.

Drip irrigation water was applied through drip rings having a radius of $6 \mathrm{~cm}$ with discharge rates calibrated at $6 \mathrm{~L} \cdot \mathrm{h}^{-1}$. Pots were watered daily, with irrigation depths based on daily water loss from reference pots placed between treatments. Subirrigation water was injected at the bottom of sealed pots to maintain the water table 20 to $25 \mathrm{~cm}$ below the soil surface. An overview of weekly irrigation depths applied to the treatments is presented in Fig. 1.

The EC of the irrigation water was increased by adding a concentrated solution of synthetic sea water (Lunin et al., 1961) to reservoir tanks filled with tap water. This solution was added until the measured $\mathrm{EC}_{\mathrm{i}}$ (Markson conductance meter model 72) value coincided with the required $\mathrm{EC}_{\mathrm{i}}$ value. The tap water used to fill the tanks averaged $\left(\mathrm{mg} \cdot \mathrm{L}^{-1}\right)$ :
$\mathrm{Ca}, 28 ; \mathrm{Mg}, 18 ; \mathrm{Na}, 10$; and $\mathrm{Cl}, 29$; and a $\mathrm{pH}$ of 7.7. Tensiometers (30-cm type; Irrometer Corp., Riverside, Calif.) were placed in the drip-irrigated pots and average preirrigation values readings for the intermediate salinity treatment are shown in Fig. $2 \mathrm{~A}$ and B. The EC of the leachate with the Drip 1.50 $_{\text {treatment was }}$ measured weekly and values are presented in Fig. $3 \mathrm{~A}$ and $\mathrm{B}$.

Bean stands were thinned to three plants per pot after emergence. Two plants per pot were sampled at 2 weeks and one plant at 3 weeks after emergence. Tomato plants were pruned to a single stem and trained along nylon strings. Aboveground plant parts of one plant were sampled three times as follows:

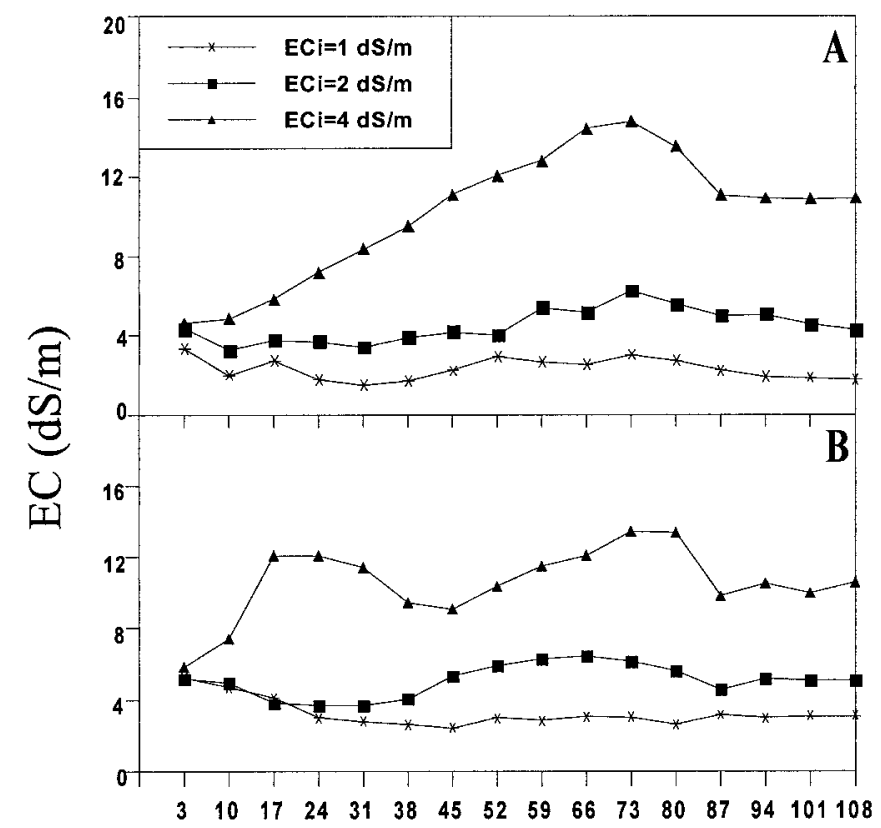

Fig. 3. Electrical conductivity of leachate collected from pots of the Drip ${ }_{1.50}$ treatment for Expt. 1 (A) and Expt. 2 (B). 
Table 3. Main effects of experiment, irrigation, and salinity treatments on germination percentage for bean, plant height for bean and tomato, and stem diameter for tomato.

\begin{tabular}{|c|c|c|c|c|c|c|c|}
\hline \multirow[b]{3}{*}{ Treatment } & \multicolumn{3}{|c|}{ Bean } & \multicolumn{4}{|c|}{ Tomato } \\
\hline & \multirow{2}{*}{$\begin{array}{c}\text { Germination }^{2} \\
(\%)\end{array}$} & \multicolumn{2}{|c|}{ Plant height $(\mathrm{cm})$} & \multicolumn{3}{|c|}{ Plant height $(\mathrm{cm})$} & \multirow{2}{*}{$\begin{array}{l}\text { Stem diameter } \\
(\mathrm{cm})\end{array}$} \\
\hline & & Week 2 & Week 4 & Week 2 & Week 4 & Week 8 & \\
\hline \multicolumn{8}{|l|}{ Experiment } \\
\hline 1 & 61.0 & 8.1 & 19.4 & 24.3 & 61.4 & 96.2 & 0.95 \\
\hline 2 & 80.3 & 10.2 & 19.3 & 35.5 & 71.3 & 108.7 & --- \\
\hline Significance & NS & $* *$ & NS & $* * *$ & $* * *$ & $* * *$ & --- \\
\hline \multicolumn{8}{|l|}{ Irrigation } \\
\hline Drip $_{0.75}$ & 84.7 & 10.1 & 21.2 & 31.7 & 66.8 & 101.1 & 0.98 \\
\hline Drip $_{1.50}$ & 86.0 & 10.0 & 20.5 & 29.6 & 66.7 & 106.1 & 0.94 \\
\hline $\mathrm{SI}^{\mathrm{x}}$ & 41.7 & 7.4 & 16.3 & 28.5 & 65.6 & 100.0 & 0.93 \\
\hline Drip $_{0.75}$ vs. ${ }_{1.50}$ & NS & NS & NS & $* *$ & NS & NS & NS \\
\hline Drip vs. SI & $* * *$ & $* * *$ & $* * *$ & $* *$ & NS & NS & NS \\
\hline \multicolumn{8}{|l|}{$\mathrm{EC}\left(\mathrm{dS} \cdot \mathrm{m}^{-1}\right)$} \\
\hline 1 & 76.4 & 10.7 & 22.5 & 31.6 & 67.8 & 103.9 & 0.98 \\
\hline 2 & 75.0 & 9.5 & 20.5 & 30.2 & 67.7 & 106.1 & 0.98 \\
\hline 4 & 61.1 & 7.3 & 15.0 & 27.9 & 63.6 & 97.3 & 0.89 \\
\hline Significance & $\mathrm{L}^{*}$ & $\mathrm{~L}^{* * * *}$ & $\mathrm{~L}^{* * * *}$ & $\mathrm{~L}^{* * * *}$ & $\mathrm{~L}^{*}$ & $\mathrm{~L}^{*}$ & $\mathrm{~L}^{* *}$ \\
\hline
\end{tabular}

${ }^{\mathrm{z}}$ Six days after planting.

${ }^{\mathrm{y}}$ Measured at the fifth node 5 weeks after transplanting; measurements taken only during Expt. 1. xubirrigation.

Ns, *,******N Nonsignificant or significant at $P \leq 0.05,0.01$, and 0.001 , respectively, and linear (L) or quadratic (Q).

initial growth, initial flowering, and crop maturation [3, 5, and 17 weeks, respectively (Expt. 1) and at 2, 4, and 16 weeks, respectively (Expt. 2)]. During the first experiment, stem diameter at the fifth leaf node was measured 5 weeks after transplanting. Leaf area of each plant was determined with a portable leaf area meter(LI-COR 3050; LI-COR, Lincoln, Nebr.) and shoot dry weights were measured by drying each plant $\left(72 \mathrm{~h}, 70^{\circ} \mathrm{C}\right)$ in a forced-air drying oven. Recently matured leaves were sampled between 1100 and $1300 \mathrm{HR}$ EST, and leaf water potential was measured with a pressure bomb (Model 3005; Soil Moisture Equipment Corp., Santa Barbara, Calif.). Tissue samples $(250 \mathrm{mg})$ were digested with sulfuric acid $(96 \%)$ and hydrogen peroxide (30\%). Kjeldahl $\mathrm{N}$ and $\mathrm{P}$ were determined with a rapid flow analyzer (Alpkem Rapid Flow Analyzer, Silver Spring, Md.), and $\mathrm{K}, \mathrm{Ca}, \mathrm{Mg}$, and $\mathrm{Na}$ were determined by atomic absorption spectrometry. Mature fruit were harvested and graded into marketable and cull fruit (fruits diameter $<57 \mathrm{~mm}$ or with a weight $<90 \mathrm{~g}$ were culls).

Analysis of variance of data were calculated using SAS 6.03 (SAS Institute, Cary, N.C.). Data for the two experiments were combined and orthogonal contrasts were used to compare drip treatments (Drip ${ }_{0.75} \mathrm{vs}_{1_{1.50}}$ refers to significant effects between drip water quantities), drip irrigation vs. subirrigation (Drip vs. SI), and salinity concentration efmain effects only are presented unless interactions were significant. fects [linear (L) or quadratic (Q)]. Data for

\section{Results and Discussion}

Effects of irrigation and salinity treatments on shoot growth. Overall plant height and shoot weight of both crops were greater during the second experiment (Table 3 ), probably because initial temperature and light intensity were higher than during Expt. 1. With subirrigation, plant growth was relatively poor and was affected more by an increase in salinity, resulting in relatively low transpiration losses from subirrigated pots. This effect was most pronounced during the second experiment because of the larger pot size and the greater water-holding capacity of the soil used. Higher soil-moisture levels may have increased oxygen stress and further reduced plant growth.

Bean seed germination percentage and plant height were greater with drip irrigation than with subirrigation. Tomato plant height during initial growth was greater with drip than with subirrigation, and decreased with an increase in drip irrigation rate (Table 3 ). Bean and tomato plant heights decreased linearly with an increase in the salinity of the irrigation water, in agreement with results reported for beans by Zaiter and Mahfouz (1993). Stem diameter of tomato plants was not affected by irrigation method but decreased linearly with an increase in salinity.

Fresh weight of bean shoots, but not tomato plants, increased in water application rate with drip irrigation (Table 4). Bean fresh and dry shoot weights and tomato leaf and stem weights were greater with drip than with subirrigation. Bean fresh and dry shoot weights decreased linearly with an increase in salinity, in agreement with a report by Campbell et al. (1986). An increase in salinity during initial vegetative growth resulted in a quadratic decrease in fresh and dry weight of tomato stems and leaves (Table 4). At flowering, fresh and dry weights of tomato stems decreased linearly with an increase in salinity, while leaf

Table 4. Main effects of experiment, irrigation, and salinity on fresh (FW) and dry weight (DW) (g) of bean and tomato plants.

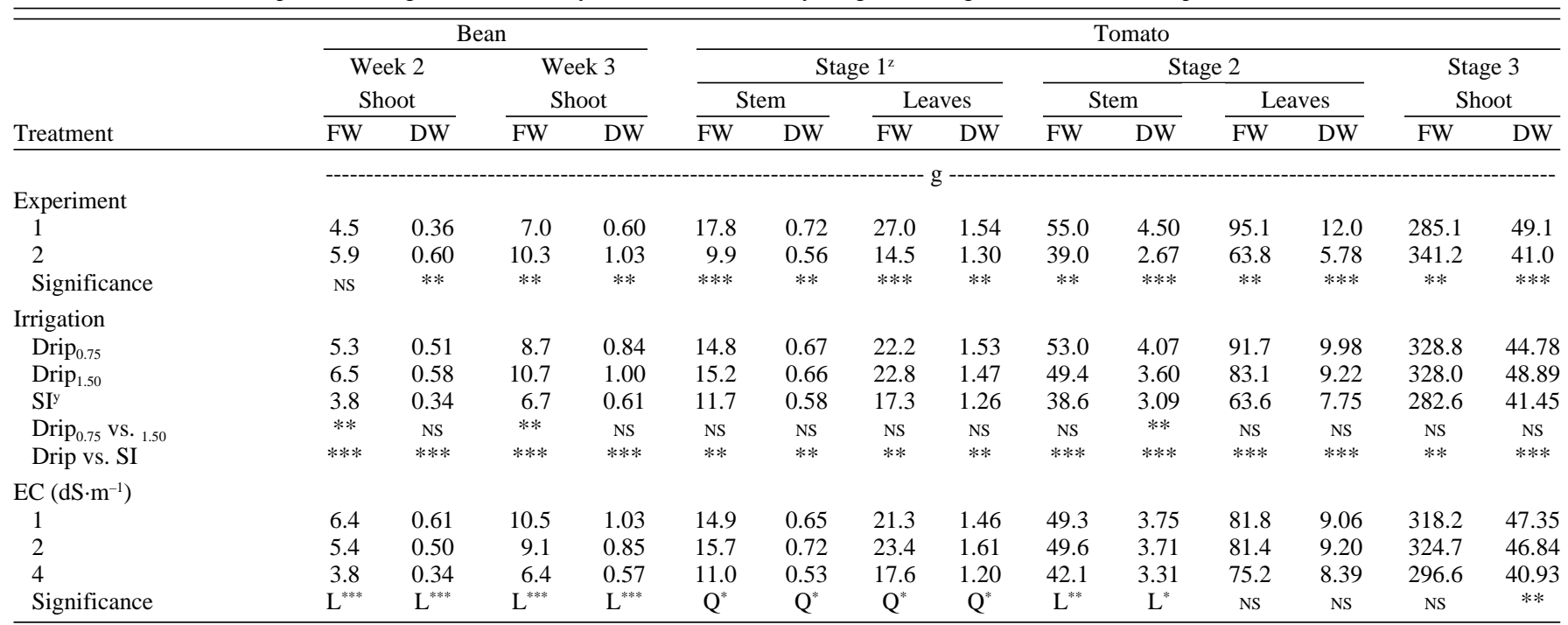

${ }^{2}$ Developmental stage 1: initial vegetative growth (2-3 weeks after transplanting); 2: initial flowering (4-5 weeks after transplanting); 3: harvesting maturity (67 weeks after transplanting).

${ }^{\mathrm{y}}$ Subirrigation.

Ns, ${ }^{*}, * *{ }^{* * *}$ Nonsignificant or significant at $P \leq 0.05,0.01$, and 0.001 , respectively, and linear $(\mathrm{L})$ or quadratic $(\mathrm{Q})$. 
Table 5. Main effects of experiment, irrigation, and salinity treatments on leaf area and leaf water potential (LWP) for bean and tomato.

\begin{tabular}{|c|c|c|c|c|c|c|c|}
\hline \multirow[b]{3}{*}{ Treatment } & \multicolumn{3}{|c|}{ Bean } & \multicolumn{4}{|c|}{ Tomato } \\
\hline & \multicolumn{2}{|c|}{ Leaf area $\left(\mathrm{cm}^{2}\right)$} & \multirow{2}{*}{$\frac{\text { LWP }(\mathrm{MPa})}{\text { Week } 3}$} & \multicolumn{2}{|c|}{ Leaf area $\left(\mathrm{cm}^{2}\right)$} & \multicolumn{2}{|c|}{ LWP (MPa) } \\
\hline & Week 2 & Week 3 & & Stage $1^{z}$ & Stage 2 & Stage 1 & Stage 2 \\
\hline \multicolumn{8}{|l|}{ Experiment } \\
\hline 1 & 137 & 264 & -0.27 & 902 & 2941 & -0.32 & -0.07 \\
\hline 2 & --- & --- & --- & 530 & 1901 & -0.35 & -0.54 \\
\hline Significance & --- & --- & --- & $* * *$ & $* * *$ & NS & $* * *$ \\
\hline \multicolumn{8}{|l|}{ Irrigation } \\
\hline Drip $_{0.75}$ & 152 & 262 & -0.28 & 764 & 2746 & -0.26 & -0.37 \\
\hline Drip $_{150}$ & 163 & 283 & -0.14 & 749 & 2485 & -0.30 & -0.23 \\
\hline $\mathrm{SI}^{\mathrm{y}}{ }^{-}$ & 97 & 246 & -0.38 & 635 & 2031 & -0.44 & -0.33 \\
\hline Drip $_{0.75}$ vs. ${ }_{1.50}$ & NS & NS & $* *$ & NS & * & NS & ** \\
\hline Drip vs. SI & $* *$ & NS & ** & ** & $* * *$ & $* *$ & NS \\
\hline \multicolumn{8}{|l|}{$\mathrm{EC}\left(\mathrm{dS} \cdot \mathrm{m}^{-1}\right)$} \\
\hline 1 & 161 & 292 & -0.28 & 730 & 2416 & -0.30 & -0.22 \\
\hline 2 & 148 & 285 & -0.21 & 784 & 2492 & -0.37 & -0.26 \\
\hline 4 & 103 & 214 & -0.32 & 635 & 2355 & -0.33 & -0.44 \\
\hline Significance & $\mathrm{L}^{* *}$ & NS & $\mathrm{Q}^{*}$ & $\mathrm{Q}^{*}$ & NS & NS & $\mathrm{L}^{* * *}$ \\
\hline
\end{tabular}

${ }^{2}$ Developmental stage 1: initial vegetative growth (2-3 weeks after transplanting); 2: initial flowering (45 weeks after transplanting); 3 : harvesting maturity (6-7 weeks after transplanting).

'Subirrigation.

Ns, *,*******Nonsignificant or significant at $P \leq 0.05,0.01$, and 0.001 , respectively, and linear (L) or quadratic (Q).

weights were not affected. At crop maturity, fresh weight was unaffected, but dry-matter accumulation decreased linearly with increased salinity. Leaf weight at flowering appeared to be relatively insensitive to salinity, in contrast with the linear decrease in shoot dry weights reported with a similar range of $\mathrm{EC}_{\mathrm{i}}$ values (Bolarin et al., 1993). The linear reduction in stem weight of tomato with increased salinity coincided with a decrease in stem diameter (data not shown). Stem diameter measurements taken at the youngest fully developed node may thus be a fairly reliable indicator of salinity stress in tomato plants.

Drip irrigation rate had no effect on bean leaf area (Table 5). During initial growth and flowering, tomato leaf areas were unaffected or decreased with an increase in irrigation rate, respectively. Leaf areas of tomato and bean at week 2 were greater with drip than with subir- rigation. Bean leaf area decreased linearly at week 2, and tomato leaf area responded quadratically with increased salinity at stage 1 . Enhanced early growth of tomato with the intermediate salinity treatment may have been due to the addition of plant nutrients to irrigation water (Bolarin et al., 1993). With a further increase in solute concentration and/or during a latergrowth phase, beneficial effects were readily offset by increased ionic and osmotic stresses.

Bean leaf water potential $\left(\Psi_{1}\right)$ increased or became less negative with an increase in drip irrigation rate, and was lower with drip than with subirrigation (Table 5). With tomato, $\Psi_{1}$ was unaffected or decreased with drip irrigation rate during initial growth and flowering, respectively. During initial growth, tomato $\Psi_{1}$ was unaffected by salinity treatments; however, at flowering, $\Psi_{1}$ decreased linearly with increasing salinity (Table 5). With the Drip ${ }_{1.50}$ treatment, bean fresh shoot weights were greater where $\Psi_{1}$ values were less negative. This could be related to the relatively low water and salinity stress associated with an overall higher soil moisture content and the leaching of ions below the root zone. In the first experiment, the lower values of $\Psi_{1}$ for tomato during flowering were likely related to overcast weather conditions during sampling. The lack of response of drip-irrigated tomato to irrigation rate at the first sampling (stage 1) may thus be related to low initial moisture stress. At planting, the soil was at "field capacity," and soil moisture depletion was low because of the small plant size. Only after 3 to 4 weeks did the decrease in soil matric potential became appreciable (Fig. 2 A and B). Effects of moisture stress and accumulation of solutes in the soil profile on $\Psi_{1}$ for tomato (not measured in subirrigated pots), a relatively salttolerant crop, therefore only became discernible at flowering (stage 2).

Effects of irrigation and salinity treatments on shoot $\mathrm{N}, \mathrm{P}, \mathrm{K}, \mathrm{Ca}, \mathrm{Mg}$, and Na ion concentrations. Bean and tomato leaf tissue concentrations of $\mathrm{N}, \mathrm{P}, \mathrm{K}, \mathrm{Ca}$, and $\mathrm{Na}$ were higher in the first than in the second experiment, while the reverse was true for $\mathrm{Mg}$ concentrations at week 2 (Tables 6 and 7). Concentrations of most minerals (except for $\mathrm{Na}$ ) fell within the adequate range for bean and tomato (Hochmuth et al., 1991). Tomato $\mathrm{P}$ concentrations were higher with drip irrigation than with subirrigation (Table 6). With an increase in drip irrigation rate, $\mathrm{N}$ concentration of bean decreased and $\mathrm{P}$ increased in leaves of both species. The increase in bean $\mathrm{P}$ content was significant only during initial growth. The decrease in $\mathrm{N}$ concentration may have been related to an increase in leaching. Tomato tissue $\mathrm{N}$ concentrations decreased at stage 1 , and increased linearly at stage 2 , with an increase in salinity of the irrigation water. Bean $\mathrm{K}$ concentrations increased with increased salinity, whereas with tomato at the flowering stage, the reverse occurred (Table 6).

Table 6. Main effects of experiment, irrigation and salinity treatments on leaf tissue $\mathrm{N}, \mathrm{P}$, and $\mathrm{K}$ concentrations $\left(\mathrm{g} \cdot \mathrm{kg}^{-1}\right)$ for bean and tomato.

\begin{tabular}{|c|c|c|c|c|c|c|c|c|c|c|c|c|}
\hline \multirow[b]{3}{*}{ Treatment } & \multicolumn{6}{|c|}{ Bean } & \multicolumn{6}{|c|}{ Tomato } \\
\hline & \multicolumn{2}{|c|}{$\begin{array}{c}\mathrm{N} \\
\text { Week }\end{array}$} & \multicolumn{2}{|c|}{$\begin{array}{c}\mathrm{P} \\
\text { Week }\end{array}$} & \multicolumn{2}{|c|}{$\begin{array}{c}\mathrm{K} \\
\text { Week }\end{array}$} & \multicolumn{2}{|c|}{$\begin{array}{c}\mathrm{N} \\
\text { Stage }^{z}\end{array}$} & \multicolumn{2}{|c|}{$\begin{array}{c}P \\
\text { Stage }\end{array}$} & \multicolumn{2}{|c|}{$\begin{array}{c}\mathrm{K} \\
\text { Stage }\end{array}$} \\
\hline & 2 & 3 & 2 & 3 & 2 & 3 & 1 & 2 & 1 & 2 & 1 & 2 \\
\hline 1 & 50.6 & 36.8 & 5.1 & 3.9 & 40.4 & 39.3 & 52.3 & 34.5 & 5.5 & 4.5 & 51.7 & 37.6 \\
\hline 2 & 37.2 & 27.8 & 3.1 & 3.3 & 31.0 & 30.4 & 44.8 & 50.9 & 2.5 & 4.4 & 28.0 & 34.0 \\
\hline Significance & $* * *$ & $* * *$ & $* * *$ & $* * *$ & $* *$ & $* *$ & $* * *$ & $* * *$ & $* * *$ & NS & $* * *$ & NS \\
\hline Drip $_{1.50}$ & 42.3 & 30.1 & 4.3 & 3.7 & 38.3 & 35.3 & 47.4 & 40.7 & 4.3 & 5.3 & 40.4 & 35.3 \\
\hline $\mathrm{SI}^{\mathrm{y}}$ & 43.8 & 31.4 & 4.2 & 3.5 & 34.7 & 35.7 & 47.7 & 45.2 & 3.7 & 3.8 & 39.8 & 36.1 \\
\hline Drip $_{0.75}$ vs. ${ }_{1.50}$ & $* *$ & $* * *$ & $* *$ & NS & $* *$ & NS & $* *$ & NS & $*$ & $*$ & NS & NS \\
\hline Drip vs. SI & NS & NS & NS & NS & NS & NS & NS & NS & $* * *$ & $* *$ & NS & NS \\
\hline \multicolumn{13}{|l|}{$\mathrm{EC}\left(\mathrm{dS} \cdot \mathrm{m}^{-1}\right)$} \\
\hline 1 & 43.1 & 31.5 & 3.9 & 3.5 & 32.6 & 31.1 & 49.2 & 40.1 & 4.0 & 4.5 & 39.0 & 38.1 \\
\hline 2 & 44.1 & 32.3 & 4.1 & 3.7 & 35.8 & 35.2 & 49.5 & 42.2 & 4.1 & 4.4 & 41.1 & 36.2 \\
\hline
\end{tabular}

${ }^{2}$ Developmental stage 1: initial vegetative growth (2-3 weeks after transplanting); 2 : initial flowering (4-5 weeks after transplanting); 3 : harvesting maturity (6-

7 weeks after transplanting).

y Subirrigation.

ss, ********Nonsignificant or significant at $P \leq 0.05,0.01$, and 0.001 , respectively, and linear (L) or quadratic (Q). 
Table 7. Main effects of experiment, irrigation, and salinity treatments on leaf tissue $\mathrm{Ca}, \mathrm{Mg}$, and $\mathrm{Na}$ concentration ( $\mathrm{g} \cdot \mathrm{kg}^{-1}$ ) for bean and tomato.

\begin{tabular}{|c|c|c|c|c|c|c|c|c|c|c|c|c|}
\hline \multirow[b]{3}{*}{ Treatment } & \multicolumn{6}{|c|}{ Bean } & \multicolumn{6}{|c|}{ Tomato } \\
\hline & \multicolumn{2}{|c|}{$\begin{array}{c}\mathrm{Ca} \\
\text { Week }\end{array}$} & \multicolumn{2}{|c|}{$\begin{array}{c}\mathrm{Mg} \\
\text { Week }\end{array}$} & \multicolumn{2}{|c|}{$\begin{array}{c}\mathrm{Na} \\
\text { Week }\end{array}$} & \multicolumn{2}{|c|}{$\begin{array}{c}\mathrm{Ca} \\
\text { Stage }^{z}\end{array}$} & \multicolumn{2}{|c|}{$\begin{array}{c}\mathrm{Mg} \\
\text { Stage }\end{array}$} & \multicolumn{2}{|c|}{$\begin{array}{c}\mathrm{Na} \\
\text { Stage }\end{array}$} \\
\hline & 2 & 3 & 2 & 3 & 2 & 3 & 1 & 2 & 1 & 2 & 1 & 2 \\
\hline \multicolumn{13}{|l|}{ Experiment } \\
\hline 1 & 1.98 & 2.44 & 0.35 & 0.39 & 0.15 & 0.18 & 2.58 & 1.62 & 0.45 & 0.31 & 0.61 & 0.43 \\
\hline 2 & 1.40 & 1.49 & 0.42 & 0.43 & 0.09 & 0.13 & 1.51 & 1.09 & 0.63 & 0.47 & 0.29 & 0.24 \\
\hline Significance & $* * *$ & $* * *$ & $*$ & NS & NS & NS & $* * *$ & $* *$ & $* * *$ & $* * *$ & $* * *$ & $* * *$ \\
\hline \multicolumn{13}{|l|}{ Irrigation } \\
\hline Drip $_{0.75}$ & 1.72 & 2.14 & 0.39 & 0.43 & 0.09 & 0.13 & 1.99 & 1.33 & 0.54 & 0.42 & 0.47 & 0.30 \\
\hline Drip $_{1.50}$ & 1.78 & 1.89 & 0.36 & 0.37 & 0.11 & 0.12 & 2.00 & 1.27 & 0.52 & 0.34 & 0.51 & 0.27 \\
\hline $\mathrm{SI}^{\mathrm{y}}$ & 1.58 & 1.86 & 0.41 & 0.43 & 0.17 & 0.22 & 2.14 & 1.46 & 0.56 & 0.41 & 0.37 & 0.43 \\
\hline Drip $_{0.75}$ vs. ${ }_{1.50}$ & NS & $* *$ & NS & $* * *$ & NS & NS & NS & NS & NS & $* * *$ & NS & NS \\
\hline Drip vs. SI & $*$ & NS & $*$ & $*$ & $* * *$ & $* *$ & NS & $* *$ & NS & $*$ & $* * *$ & $* *$ \\
\hline \multicolumn{13}{|l|}{$\mathrm{EC}\left(\mathrm{dS} \cdot \mathrm{m}^{-1}\right)$} \\
\hline 1 & 1.62 & 1.77 & 0.36 & 0.40 & 0.08 & 0.09 & 2.08 & 1.36 & 0.54 & 0.39 & 0.29 & 0.22 \\
\hline 2 & 1.66 & 1.97 & 0.37 & 0.41 & 0.10 & 0.10 & 1.95 & 1.35 & 0.53 & 0.39 & 0.38 & 0.31 \\
\hline 4 & 1.79 & 2.15 & 0.43 & 0.42 & 0.19 & 0.28 & 2.10 & 1.35 & 0.55 & 0.39 & 0.68 & 0.46 \\
\hline Significance & $\mathrm{L}^{*}$ & $\mathrm{~L}^{* * *}$ & $\mathrm{~L}^{* * * *}$ & NS & $\mathrm{L}^{* * *}$ & $\mathrm{~L}^{* *}$ & NS & NS & NS & NS & $\mathrm{L}^{* * *}$ & $\mathrm{~L}^{* * *}$ \\
\hline
\end{tabular}

${ }^{2}$ Fruits $<57 \mathrm{~mm}$ in diameter or $<90 \mathrm{~g}$ in weight were considered to be culls.

${ }^{\mathrm{y}}$ Subirrigation.

ns, *,**,***N Nonsignificant or significant at $P \leq 0.05,0.01$, and 0.001 , respectively, and linear (L) or quadratic (Q).

Concentrations of $\mathrm{Ca}$ and $\mathrm{Mg}$ in bean at week 3, and $\mathrm{Mg}$ concentrations of tomato at initial flowering, were reduced with an increase in drip irrigation rate (Table 7). Concentrations of $\mathrm{Mg}$ and $\mathrm{Na}$ in bean, and $\mathrm{Ca}, \mathrm{Mg}$, and $\mathrm{Na}$ at initial flowering in tomato, were lower with drip than with subirrigation. For bean, concentrations of $\mathrm{Ca}, \mathrm{Mg}$ (at week 2), and $\mathrm{Na}$ increased linearly with an increase in $\mathrm{EC}_{\mathrm{i}}$, whereas for tomato, this response was only observed with $\mathrm{Na}$. Increased uptake of $\mathrm{Na}, \mathrm{Ca}$, and $\mathrm{Mg}$ was probably related to the addition of these ions to the irrigation water. Observed differences between bean and tomato could have been related to selective uptake of $\mathrm{Mg}$ and $\mathrm{Ca}$ and/or to competition with $\mathrm{Na}$ for uptake.

Plant accumulation of salts (especially $\mathrm{Na}$ ) appeared to be affected by both irrigation systems. In Expt. 1, irrigation and salinity treatments interacted in their effects on $\mathrm{Na}$ concentrations of bean at week 3 and for tomato during flowering. As $\mathrm{EC}_{\mathrm{i}}$ increased from 1 to $4 \mathrm{dS} \cdot \mathrm{m}^{-1}$, Na concentrations of bean increased from 0.13 to 0.16 (NS), from 0.07 to $0.20\left(\mathrm{~L}^{*}\right)$, and from 0.08 to $0.47\left(\mathrm{~L}^{* * *}\right)$ with the Drip $_{0.75}$, Drip ${ }_{1.50}$, and SI treatments, respectively. Sodium concentrations during initial flowering for tomato increased from 0.22 to $0.56\left(\mathrm{~L}^{* * *}\right)$, from 0.24 to $0.38\left(\mathrm{~L}^{* *}\right)$, and from 0.30 to $0.93\left(\mathrm{~L}^{* * *}\right)$ with the Drip $_{0.75}$, Drip $_{1.50}$, and SI treatments, respectively. Increases in $\mathrm{Na}$ concentrations were probably caused by the accumulation of solutes along the periphery of the wetting front $\left(\right.$ Drip $\left._{0.75}\right)$ and within the root zone (SI).

The overall reduction in plant growth and increase in uptake of $\mathrm{Na}$ with the use of saline water was more pronounced with subirrigated than with drip-irrigated crops. The use of subirrigation resulted in the upward flow of water and salt accumulation in the upper (aerobic) part of the rhizosphere. At harvest, salt concentrations in the soil at 0 - to $2.5-\mathrm{cm}$ depth were $1.78,0.85$, and $6.87 \mathrm{dS} \cdot \mathrm{m}^{-1}$, with Drip 0.75 , Drip $_{1.50}$, and SI treatments, respectively. With drip irrigation, the maintenance of a moist, highly leached root zone reduces the detrimental effects of salinity on plant growth. The more pronounced growth reductions caused by increased salinity under excessively moist conditions reported here are in agreement with reports by Parra and Cruz Romero (1980).

Fruit yield and fruit size. Total fruit yield, marketable fruit yield, and average fruit weight of tomato were higher with drip than with subirrigation (Table 8). Marketable and total fruit yield increased with an increase in drip irrigation rate and decreased with an increase in salinity. Overall yield reductions in response to increased salinity appear to be similar to those reported by Bolarin et al. (1993). The reduction in marketable fruit yield due to salinity was very pronounced (quadratic) and was related to a reduction in both fruit size and fruit number. At Drip ${ }_{1.50}$, salt accumulation in the leachate was much greater with $4 \mathrm{dS} \cdot \mathrm{m}^{-1}$ than with 1 or $2 \mathrm{dS} \cdot \mathrm{m}^{-1}$ (Fig. 3). The drastic decrease in fruit size was at variance with reports by Vinten et al. (1985). In their study, fruit number was affected more by salinity than was fruit weight. With a decrease in fruit size the increase in the percentage of cull fruits can be appreciable.

With typical Florida weather conditions, optimal irrigation management appears to be of foremost importance when using low-quality irrigation water. Irrigation rates in excess of crop water requirements during initial crop development may cause more rapid salinization of the (initial) nonsaline soil profile and may also increase $\mathrm{N}$ losses (Meiri and Plaut, 1986). With low water use efficiencies, as is typical with subirrigation, mitigating effects of additional rainfall on leaching and/or dilution of solutes also become less pronounced. With subirrigation, both the accumulation of solutes in the topsoil as well as excessively high soil moisture in the root zone must be prevented to prevent yield reductions.

Table 8. Main effects of experiment, irrigation, and salinity treatments on total fruit yield, marketable fruit yield, and average fruit weight for tomato.

\begin{tabular}{|c|c|c|c|c|c|}
\hline \multirow[b]{2}{*}{ Treatment } & \multicolumn{2}{|c|}{ Total fruit yield } & \multicolumn{2}{|c|}{ Marketable fruit yield ${ }^{z}$} & \multirow[b]{2}{*}{$\begin{array}{l}\text { Avg fruit wt } \\
\text { (g/fruit) }\end{array}$} \\
\hline & Number & $\begin{array}{r}\text { Weight } \\
\text { (g/plant) }\end{array}$ & Number & $\begin{array}{l}\text { Weight } \\
\text { (g/plant) }\end{array}$ & \\
\hline \multicolumn{6}{|l|}{ Experiment } \\
\hline 1 & 11.5 & 1032 & 3.3 & 476 & 85.1 \\
\hline 2 & 13.1 & 1016 & 2.4 & 359 & 77.0 \\
\hline Significance & NS & NS & $*$ & NS & NS \\
\hline \multicolumn{6}{|l|}{ Irrigation } \\
\hline Drip $_{0.75}$ & 11.2 & 781 & 1.4 & 188 & 66.8 \\
\hline Drip $_{1.50}$ & 13.5 & 1378 & 5.1 & 784 & 103.1 \\
\hline $\mathrm{SI}^{\mathrm{y}}$ & 12.1 & 913 & 2.1 & 280 & 71.8 \\
\hline Drip $_{0.75}$ vs. ${ }_{1.50}$ & $*$ & $* * *$ & $* * *$ & $* * *$ & $* * *$ \\
\hline Drip vs. SI & NS & $* *$ & $*$ & $* *$ & $* * *$ \\
\hline \multicolumn{6}{|l|}{$\mathrm{EC}\left(\mathrm{dS} \cdot \mathrm{m}^{-1}\right)$} \\
\hline 1 & 14.1 & 1417 & 5.3 & 802 & 102.8 \\
\hline 2 & 12.7 & 1055 & 2.6 & 376 & 83.0 \\
\hline 4 & 10.0 & 601 & 0.6 & 75 & 57.4 \\
\hline Significance & $\mathrm{L}^{* * *}$ & $\mathrm{~L}^{* * * *}$ & $\mathrm{Q}^{*}$ & $\mathrm{Q}^{* *}$ & $\mathrm{~L}^{* * *}$ \\
\hline
\end{tabular}

${ }^{2}$ Developmental stage 1: initial vegetative growth (2-3 weeks after transplanting); 2: initial flowering (45 weeks after transplanting); 3 : harvesting maturity (6-7 weeks after transplanting).

y Subirrigation.

ns, *,**,*** Nonsignificant or significant at $P \leq 0.05,0.01$, and 0.001 , respectively, and linear (L) or quadratic (Q). 


\section{Literature Cited}

Ayers, R.S. and D.W. Westcott. 1976. Water quality evaluation, p. 400-431. In: Managing saline water for irrigation. Proc. Intl. Salinity Conf., Lubbock, Tex.

Bolarin, M.C., F. Perez-Alfacea, E.A. Cano, M.T. Estan, and M. Caro. 1993. Growth, fruit yield, and ion concentration in tomato genotypes after pre-and post-emergence salt treatments. J. Amer. Soc. Hort. Sci. 118:655-660.

Campbell, W.F., R.J. Wagenet, and R.R. Rodriguez. 1986. Salinity, water management, and fertility interactions on yield and nitrogen fixation in snap-beans. Irr. Sci. 7:195-204.

Goertz, S. and J.M. Coons. 1991. Tolerance of tepary and navy beans to $\mathrm{NaCl}$ during germination and emergence. HortScience 26:246-249.

Hochmuth, G.J., D. Maynard, C. Vavrina, and E.A. Hanlon. 1991. Plant tissue analysis and interpretation for vegetable crops in Florida. SS-VEC42. Univ. of Florida, Gainesville.
Hoffman, G.J. 1986. Managing saline water for crop production, p. 361-388. In: A. Ahmad and A. San Pietro (eds.). Prospects for biosaline research. Botany Dept., Karachi Univ., Pakistan.

Locascio, S.J. and A.G. Smajstrla. 1996. Water application scheduling by pan evaporation for drip-irrigated tomato. J. Amer. Soc. Hort. Sci. 121:63-68.

Lunin, J., M.H. Gallatin, and A.R. Batchelder. 1961. Effect of stage of growth at time of salinization on the growth and chemical composition of beans: II. Salinization in one irrigation compared with gradual salinization. Soil Sci. 91:194-202.

Meiri, A. and Z. Plaut. 1985. Crop production and management under saline conditions. Plant Soil 89:253-271.

Mitchell, J.P., C. Shennan, and S.R. Grattan. 1991. Developmental changes in tomato fruit composition in response to water deficit and salinity. Physiol. Plant. 83:177-185.

Parra, M.A. and G. Cruz Romero. 1980. On the dependence of salt tolerance of beans (Phaseolus vulgaris $\mathrm{L}$.) on soil matric potentials. Plant Soil 56:3-16.

Pasternak, D. 1987. Salt tolerance and crop production-A comprehensive approach. Annu. Rev. Phytopath. 25:271-291.

Pitts, D.J., G.A. Clark, J. Alvarez, P.H. Everett, and J.M. Grimm. 1988. A comparison of micro to subsurface irrigation of tomatoes. Proc. Fla. State Hort. Soc. 101:393-397.

Steinkampf, W.C. 1982. Origins and distribution of saline ground water in the Florida aquifer in coastal southwest Florida. U.S. Geol. Survey. Water Resource Invest. 82-4052. Tallahassee, Fla.

Vinten, A., J. Shalhavet, A. Meiri, and J. Peretz. 1986. Water and leaching requirements of industrial tomatoes irrigated with brackish water. Irr. Sci. 7:13-25.

Zaiter, H. and B. Mahfouz. 1993. Salinity effect on root and shoot characteristics of common and tepary beans evaluated under hydroponic and sand culture. J. Plant Nutr. 16:1569-1592. 